\title{
Pasar Tradisional Dan Mobilitas Pedagang Di Wilayah Gunungkidul (Kajian Awai Etnoarkeologi)
}

\section{Hari Lelono}

Keywords: archaeology of economy, traditional, market, ethnoarchaeology, ethnography

\section{How to Cite:}

Lelono, H. (1999). Pasar Tradisional Dan Mobilitas Pedagang Di Wilayah Gunungkidul (Kajian Awai Etnoarkeologi). Berkala Arkeologi, 19(2), 95-103. https://doi.org/10.30883/jba.v19i2.825

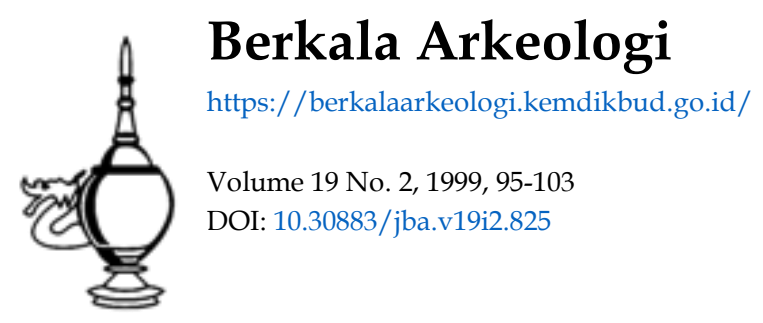

\section{c) (i) (2)}

This work is licensed under a Creative Commons Attribution-NonCommercial-ShareAlike 4.0 International License. 


\title{
PASAR TRADISIONAL DAN MOBILITAS PEDAGANG DI WILAYAH GUNUNGKIDUL (Kajian Awal Etnoarkeologi)"
}

\author{
T.M. Hari Lelono \\ (Balai Arkeologi Yogyakarta)
}

\section{Pendahuluan}

Studi tentang pasar tradisional masih belum banyak dilakukan oleh para peneliti arkeologi, mungkin karena kurangnya minat untuk melakukan studi tersebut. Padahal, jika dicermati dengan seksama pasar-pasar tradisional yang tersebar di kota-kotal desa- desa Jawa, mengandung fenomena-fenomena sosial, ekonomis, budaya, dan teknologis yang mencerminkan suatu tradisi yang sudah ada sejak masa klasik, yakni pengaruh kebudayaan Hindhu dan Budha di Jawa/Bali. Untuk dapat memperoleh gambaran pasar pada masa lalu tersebut dapat dilakukan melalui dua data, yakni budaya materi dan informasi dari masa lalu (etnografis) dan melakukan analogi dengan pasar-pasar tradisional yang masih ada.

Sebelum melangkah pada pasar perlu diketahui budaya materi terlebih dahulu, bentuk data masa lalu yang sampai ketangan arkeolog berupa data material yang terdiri dari artefak, ekofak, fitur, data keruangan situs, dan wilayah (region). Bentuk data lain adalah informasi mengenai peristiwa masa lalu dalam catatan sejarah, yang pada hakekatnya memiliki informasi langsung mengenai kehidupan masa lalu itu sendiri (konteks sistem) (Schiffer, 1976). Dengan demikian paling tidak dapat dilancarkan dua strategi pokok untuk mendapatkan gambaran ekonomi kuno, yaitu bergerak dari data masa lalu memuat informasi masa lalu (data sejarah), data masa lalu dijelaskan masa kini (data arkeologi), dan informasi masa kini untuk masa lalu (etnoarkeologi) (Schiffer, 1976; Mundardjito, 1981; Wibisono, 1988).

Mengapa studi pasar menarik untuk dilakukan penelitian,? hal tersebut menyangkut fenomena, bahwa pasar merupakan suatu sistem ekonomi kuno yang masih ada hingga saat ini memegang peranan yang sangat penting pada sistem ekonomi kuno dan bahkan saat kini-pun masih merupakan sektor yang mutlak diperlukan untuk kelangsungan eknomi dan hidup orang banyak. Di pasar terjadi interaksi antara pedagang - pembeli dan pertukaran barang dengan uang dan jasa, baik barang/jasa lokal maupun import. Dalam konteks judul di depan, batasan permasalahan hanya pada pasar-pasar tradisional, serta mobilitas yang berkaitan dengan perilaku para pedagang. Aktivitas apa yang dilakukan oleh para pedagang pasar tradisional, khususnya yang berada di dataran tinggi pegunungan selatan DI. Yogyakarta,

\footnotetext{
- Pernah disajikan pada Evaluasi Hasil Penelitian Arkeologi, Cipayung, 16--20 Februari 1998.
} 
merupakan masalah yang menarik untuk dilakukan analogi dengan daerah lingkungan yang sama, maupun lingkungan yang berbeda. Apakah terdapat persamaan atau perbedaan pola aktivitas pedagang dan pasar tradisional.

Pasar memegang peranan penting dalam suatu masyarakat dan komunitas tradisional, karena pasar merupakan suatu tempat yang menyediakan segala macam kebutuhan sehari-hari. Pasar dapat menyediakan segala macam kebutuhan sehari-hari. Pasar dapat mempunyai bermacam-macam fungsi, antara lain: fungsi ekonomis, sosial, religius dan politik. Pengertian pasar yang dimaksud adalah suatu tempat tertentu yang terorganisir dengan sekelompok bangunan, los atau bango dengan batasanbatasan yang ditentukan dimana sekelompok pembeli dan penjual bertemu, sehingga memungkinkan terjadinya transaksi jual-beli barang dan jasa (Murtolo, et.al. 1995).

Pengertian pasar tradisional adalah pasar-pasar yang sudah ada sejak masa Kerajaan Mataram Islam. Salah satu contoh pasar kuno yang masih dapat dijumpai adalah Pasar Kotagede, Yogyakarta. Pasar ini sudah ada sejak zaman Ki Gde Ageng Pemanahan. Pasar tersebut dahulu tidak seluas sekarang dan masih ditumbuhi pohon-pohon perindang. Dahulu aktivitas jual beli dilakukan di bawah pohon-pohon perindang, payung-payung penyangga dengan penjual yang duduk di atas tanah dan bukannya di los-los yang beratap permanen. Barang-barang yang diperdagangkan sebagian besar adalah hasil pertanian yang berupa beras, sayur-sayuran dan buah-buahan. Barangbarang tersebut dibawa dengan cara dipikul atau digendong dari desa dimana barang hasil bumi itu ditanam (Alibiladiyah, 1997).

Pasar tradisional selalu mempunyai hari pasaran. Hal tersebut berkaitan dengan kapan pasar-pasar tersebut ramai dikungjungi untuk melakukan transaksi. Pasar-pasar tradisional akan ramai dikunjungi oleh pembeli dan pedagang pada hari-hari tertentu yang sudah disepakati secara adat dengan mengikuti suatu pola tertentu. Pola dimaksud adalah hari pasaran yang berlaku di suatu daerah tertentu. Hari pasaran merupakan perhitungan hari atau bulan yang baik untuk melakukan sesuatu aktivitas misalkan perdagangan, yang masih dikenal oleh masyarakat Jawa dan Bali pada saat ini. Pola pasaran di Bali memakai istilah Triwara, yang kini masih dipakai sebagai hari pasaran, terdapat tiga hari pasaran dalam satu minggu, antara lain: pasah, betheng, dan kajeng (Goris, 1948). Sementara itu itu, di Jawa dikenal hari pasaran dalam satu minggu ada lima hari pasaran, antara lain: pon, wage, kliwon, legi, dan pahing (Lelono, 1994). Keberadaan pasar-pasar tradisional tersebut apakah sudah ada sejak masa klasik di Jawa? merupakan pertanyaan yang menarik untuk ditindaklanjuti. Pasar tradisional awalnya merupakan pasar-pasar kecil, saat ini banyak yang berkembang menjadi pasar-pasar besar dan moderen, tetapi sebagian besar pedagang

${ }^{1}$ Pengertian pasar tersebut adalah pasar-pasar pada masa kini dengan bangunan-bangunan los/ bango yang sudah dibatasi dengan tanda atau patok secara permanen. 
dan pasar tersebut masih mentaati tradisi yang ada, yakni dalam melakukan aktivitas pasaran memperhitungkan hari-hari pasaran.

\section{Kondisi Geografis Gunungkidul}

Keadaan alam Daerah Istimewa Yogyakarta secara umum dapat dibedakan menjadi dua wilayah yang berbeda, yakni dataran tinggi dan dataran rendah, sebagai berikut: Bagian Timur yang meliputi kurang lebih $1.487,10 \mathrm{Km}$ merupakan pegunungan kapur yang tandus dan sangat miskin akan sumber air. Termasuk daerah ini adalah Gunungkidul, terutama Rongkop dan Tepus. Jenis tanah yang terdapat di daerah ini adalah latosal dan margalit yang tidak subur. Jenis tanah serupa ini juga terdapat di daerah perbukitan kapur yang ada di Daerah Kabupaten Kulon Progo dan Bantul Bagian Tengah ke Selatan yang meliputi luas wilayah kurang lebih 1.179,53 Km merupakan daerah tanah datar yang makin ke selatan makin rendah, dan sempit (Murniatmo, 1983).

Keadaan geografis yang demikian menyebabkan daerah tersebut menjadi kurang subur. Tanahnya keras pada musim kemarau dan dapat mengakibatkan retak-retak, sedangkan pada musim penghujan merupakan tanah yang licin karena mengadung lempung, sehingga tidak memungkinkan untuk mengolah pertanian khususnya padi. Jenis tanah tersebut hanya dapat ditanamai jenis jagung, kacang-kacangan, dan ketela pohon yang relatif tidak membutuhkan air dalam jumlah yang banyak.

Kabupaten Gunungkidul dapat dibagi mejadi dua kawasan, sebelah utara Kota Wonosari merupakan kawasan yang relatif subur, dibandingkan dengan daerah di sebelah selatan. Daerah utara yang relatif lebih subur dan ramai ditandai dengan banyaknya pemukiman dengan pasar-pasar disekitarnya. Pasar-pasar tersebut antara lain di daerah Patuk, Nglipar, Ngawen, Semin, Karangmojo, Wonosari dan Playen. Di kawasan sebelah selatan, antara lain; Rongkop dan Tepus yang merupakan daerah paling tandus tidak dijumpai pasar-pasar tradisional, yang ada hanya merupakan pasar tiban. ${ }^{2}$ Hal yang sangat unik adalah bahwa, di setiap kota kecamatan terdapat pasar 'induk'/ pusat, dan di luar pusat kota pada kurang lebih radius 5 -- $7 \mathrm{Km}$ terdapat pasar-pasar tradisional yang lebih 'kecil', sehingga kalau dicermati merupakan alur atau jaringan-jaringan pasar yang saling mempunyai hubungan. Hubungan dalam hal ini adalah, pasar kecil merupakan pensuplai barang ke pasar 'induk' yang biasanya berupa hasil bumi. Sebaliknya pasar 'induk' merupakan pensuplai berupa bahan konsumsi/pertanian, obat-obatan, dan barang-barang hasil pabrikan. Dengan demikian, hubungan antara pasar induk dengan pasar-pasar disekitarnya merupakan

2 Merupakan pasar-pasar kecil yang ramai dikunjungi orang pada hari pasaran tertentu, dan kadangkala hari pasarannya tidak menentu, tergantung pada musim/cuaca. Pasar jenis ini hanya dikunjungi dan untuk konsumsi lokal/ penduduk satu desa saja. 
satu jaringan kerja yang tidak dapat dipisahkan. Hal tersebut lebih tampak nyata jika dikaitkan dengan tradisi atau hari pasaran yang berlaku pada pasar-pasar tradisional Jawa, khususnya daerah Gunungkidul.

\section{Konsep Mancapat Pada Pasar Tradisional}

Permukiman yang padat populasi penduduknya, biasanya terdapat sebuah pasar untuk memenuhi segala macam kebutuhan bagi warganya. Antara satu desa dengan desa sekitarnya mempunyai relasi yang terjalin dengan baik, dalam segi sosial, budaya, dan ekonomi. Di dalam masyarakat Jawa dikenal istilah Mancapat. Menurut Ossenbruggen, mancapat di Jawa Tengah menandakan rasa kerukunan antara sebuah desa dengan keempat desa tetangganya yang letaknya dibayangkan kira-kira di arah keempat mata angin utama dari desa tersebut. Rasa kerukunan antara desa-desa itu meluas lebih jauh, yaitu sampai ke desa-desa yang lebih jauh letaknya, dan ada pertalian dengan sistem solidaritas Jawa kuna yang sampai sekarang masih terdapat bekas-bekasnya di dalam hukum kerajaan-kerajaan Jawa Tengah selatan (Ossenbruggen, 1975).

Sistem ekonomi kuno sudah dikenal sejak masa Majapahit dimana masyarakat melakukan pertukaran barang dengan barang (barter) atau dengan jasa pada tempattempat yang telah ditentukan. Lambat laun tempat-tempat tersebut dapat diasumsikan berubah/ berkembang menjadi pasar-pasar, yakni tempat berkumpul untuk melakukan pertukaran/ perdagangan. Mengenai perdagangan pada masa Majapahit ataupun pada masa sebelumnya kita mendapatkan keterangan dari data tertulis, baik prasasti amupun naskah dan berita Cina. Dari prasasti diketahui bahwa sebelum masa Majapahit pun sudah terdapat perdagangan antar desa (lokal), antar wilayah (regional) dan internasional. Misalnya Prasasti Gondosuli I atau Puhawang Glis bertahun 827 (Nastiti, 1988).

Seperti diilustrasikan pada Prasasti Gondosuli I dan Puhawang Glis tersebut, mebuktikan bahwa terjadinya perdagangan antar desa, dan wilayah, pasti membutuhkan tempat untuk melakukan perdagangan, serta tempat penyimpanan barang (gudang). Dari tempat-tempat itulah yang lambat laun berkembang menjadi pasarpasar. Berdasarkan konsep Mancapat, desa-desa yang ada letaknya saling berdekatan, sehingga membentuk pola sebagai berikut; Terdapat desa pancer/ pokok yang berada di tengah, pada masing-masing sisi (mata angin) dikelilingi oleh empat desa lainnya. Jadi, pada sisi utara, barat, timur dan selatan terdapat desa lain. Pola ini tidak pasti, sangat tergantung kepada bentang lahan, topografis desa-desa yang ada dengan pertimbangan pada aspek strategis baik secara ekonomi, sosial, politik dan budaya. 
Pada saat ini pasar-pasar tradisional diduga letaknya berdasarkan pada pola mancapat dan hari pasaran. Pola- tersebut saling berkaitan, sehingga hari pasaran satu pasar dengan lainnya berbeda, sehingga memungkinkan pedagang melakukan aktivitasnya secara bergiliran dari satu pasar ke pasar lain, dan akan kembali ke pasar semula pada pasaran yang sama atau telah ditentukan.

Berdasarkan pengamatan sepintas yang berhasil dilakukan dapat diasumsikan, bahwa wilayah Gunungkidul bagian utara rata-rata satu pasar pusat/ induk dikelilingi oleh pasar-pasar kecil sebanyak kurang lebih empat buah. Terletak di empat penjuru mata angin, yakni disebelah utara, timur, barat dan selatan, sedangkan induknya/ pusat ada di tengah-tengah. Hal tersebut kadang dapat berubah tergantung pada kondisi geografisnya. Seperti di daerah bagian selatan hanya terdapat dua atau tiga pasar dan tidak ada pasar induk/ pusatnya. Selain itu, cenderung tidak seramai/banyak pasar dan juga lokasinya berjauhan serta tidak memiliki pola letak tertentu.

\section{Mobilitas Pedagang Pasar Tradisional}

Aktivitas yang menarik dari studi pasar tradisional adalah perilaku mobilitas para pedagang. Mobilitas yang dimaksudkan adalah, gerak perubahan antara warga masyarakat yang terjadi baik secara fisik maupun sosial (suyono, 1985). Pada konteks tersebut, pengertian mobilitas adalah aktivitas pedagang dalam usahanya menjajakan barang dagangan dari satu pasar ke pasar lainnya dalam satu kawasan atau lebih. Dalam aktivitas tersebut, pedagang dan pembeli tidak terlepas dari pengaruh lingkungan sekitarnya.

Lingkungan hidup manusia dapat digolongkan dalam beberapa kelompok yaitu lingkungan fisikal (physical enviroment), lingkungan biologis biological ebviromental) dan lingkungan sosial (social enviromental) (Bintarto dan Surastopo, 1978). Dua pengaruh yang paling dirasakan oleh pedagang dalam konteks ini, adalah lingkungan fisik dan sosial. Lingkungan fisik/ determinisme geografis berbepgaruh terhadap segala aktivitas manusia seperti daerah tersebut merupakan pegunungan kapur yang berbukit-bukit serta medan/ jalan yang terjal dan jauh, sehingga jarak jangkau dari satu pasar ke pasar lainnya menjadi terbatas. Hal tersebut dirasakan oleh para pedagang pasar tradisional dalam mobilitas yang dilakukan dari satu tempat/ pasar ke pasar lainnya. Antara satu pedagang dengan pedagang lainnya terdapat variasi/perbedaan jarak tempuh dan banyaknya jumlah pasar yang dikunjungi, tergantung pada medan dan letak geografisnya.

Pengaruh sosial bagi para pedagang adalah yang berkaitan dengan tradisi Jawa, mereka hanya melakukan perdagangan pada hari pasaran yang telah ditentukan secara tradisional. Sebuah pasar dalam lima hari hanya mengalami satu kali pasaran. Pada sat 
pasaran tersebut banyak dikunjungi dan didatangi oleh para pedagang dari berbagai daerah sekitarnya. Ciri khas hari pasaran adalah meningkatnya kegiatan dan aktivitas ekonomis, baik dari segi kuantitas maupun kualitas. Pada hari biasa pasar tersebut tidak ramai, hanya dipenuhi oleh pedagang kebutuhan sehari-hari, seperti beras dan sayur-mayur. Sedangkan pada hari pasaran barang dagangannya lebih variatif seperti: alat-alat pertanian, alat rumah tangga, dan pedagang obat-obatan. Selain itu, banyak pedagang musiman yang menggelar dagangan di luar atau pada gang-gang di dalam pasar dengan meletakkan di atas tanah beralaskan tikar, plastik, dan bakul, serta ada yang digantungkan di pohon, tergatung dari jenis barang dagangannya.

\section{Aktivitas Perdagangan di Pasar Tradisional}

Secara rinci berikut akan diulas satu persatu; (a) jenis barang konsumsi, (b) Konsumen berasal dari sekitar pasar atau dari daerah lainnya, (c) Musim ramai dan sepi, serta (d) Rotasi/ perputaran hari pasaran.

\section{Macam Barang Konsumsi}

Pengamatan dilakukan pada empat jenis pedagang, dengan asumsi bahwa jenis pedagang tersebut sudah dilakukan oleh para generasi sebelumnya. Jenis barang konsumsi yang dijual terdiri dari beberapa macam dagangan baik produk lokal maupun non-lokal, antara lain: Alat pertanian/ rumah tangga, obat-obatan/ jamu, gerabah, dan burung (kukilo)/ kesenangan. Secara rinci sebagai berikut:

a. Alat pertanian dan rumah tangga, cangkul dengan tangkai panjang atau pendek, serta mata cangkul, sabit (arit), pisau, dan bendo (pisau besar untuk membelah).

b. Obat-obatan; jamu tradisional (obat kuat) dari bahan reptil dan tumbuh-tumbuhan, ampo, obat moderen )kapsul, kaplet, dan puyer). Selain itu juga dijual obat untuk hewan (ayam, dan burung).

c. Gerabah; gentong, kendi, paso, cowek, kendil dan celengan.

d. Burung; terdiri dari jenis burung berkicau seperti jalak, kutilang, betet, gelatik, beo, derkuku, dan perkutut.

\section{Konsumen}

Pembeli secara umum dapat dibagi menjadi dua kelompok: Kelompok pertama pembeli yang bertempat tinggal di sekitar pasar; Kelompok kedua berasal dari daerah lain, kelompok ini datang ke pasar tersebut karena di tempat asalnya tidak terdapat pasar, sehingga mereka memilih pasar terdekat yang sedang berlangsung hari pasaran.

\section{Musim}

Jenis produk tertentu mengalami pasang surut pemasarannya, hal tersebut dipengaruhi oleh musim yang sedang berlangsung. Sebagai contoh, alat-alat pertanian dan obatobatan lebih laris diwaktu musim penghujan/ musim tanam. Jenis unggas (burung) 
pada musim kemarau justeru meningkat permintaannya. Hal tersebut berkaitan dengan lomba burung berkicau yang diselenggarakan pada musim kering. ${ }^{3}$

\section{Rotasi}

Aktivitas jual beli para pedagang relatif dilakukan tidak jauh dari tempat tinggalnya, utamanya para pedagang hasil bumi yang sangat dibutuhkan oleh konsumen lokal. Para pedagang ini menggunakan alat angkut seadanya, seperti dengan menggunakan sepeda yang dilengkapi dengan keranjang pada boncengan belakang di sisi kirikananya (keronjot) dilakukan oleh pedagang sayur, beras, kelapa, dan bumbu-bumbu. Ada pula yang hanya dengan di pikul dengan menggunakan alat pikulan dilakukan oleh pedagang burung ${ }^{4}$ dan minyak Selain itu ada jenis pedagang yang membawa dagangannya dengan cara digendong menggunakan tenggok dililit dengan lendang/ selendang. Gendong. Pedagang jenis tersebut perputaran/ rotasi yang dilakukan tidak terlalu jauh, dari satu pasar ke pasar yang lainnya, sehingga dapat mengandalkan alat angkut tradisional. Dalam satu musim pasaran yang telah ditetapkan pada masingmasing pasar, rata-rata dalam satu putaran pasaran mereka melakukan perdagangan sebanyak tiga kali.

Berbeda dengan jenis pedagang alat-alat pertanian atau barang pabrikan seperti bahan konveksi, mereka menggunakan alat angkut berupa mobil dan sepeda motor, sehingga jarak jelajahnya lebih jauh, dan dalam setiap musim pasaran (antar kecamatan) mereka selalu berdagang. Oleh karena itu, dalam satu putaran pasaran mereka berjulan sebanyak empat sampai lima kali. Hal tersebut dapat dibandingkan dengan pedagang tradisional yang menggunakan alat angkut sederhana, hanya berrotasi dalam satu musim pasaran sebanyak 3 kali.

\section{Penutup}

Gambaran tentang perdagangan kuno, utamanya pada masa pengaruh kebudayaan Hindhu/ Budha di Jawa, secara 'samar-samar' masih dapat dilihat pada pasar-pasar tradisional di Jawa, khususnya di daerah sekitar Surakarta dan Yogyakarta. Kedua daerah tersebut dikenal sebagai daerah 'kantong-kantong budaya Jawa'. Secara arkeologis, pasar-pasar tersebut telah berumur relatif tua, yakni sudah ada sejak masa Islam yang dilanjutkan sampai pada masa kini. Secara historis, keberadaan pasarpasar tersebut sudah ada sejak zaman Kerajaan Mataram Islam dan telah menyumbangkan peran yang sangat penting bagi kehidupan masyarakat pada waktu itu. Sedangkan secara etnografis banyak informasi yang dapat kita ketahui seperti; aktvitas, perilaku, peralatan, jenis dagangan, serta pola konsumsi masyarakat sekitar.

3 Hasil wawancara dengan Bapak Suko, Ngawen Gunungkidul 1998.

4. Hasil wawancara dengan Bapak Dalimin Manuk, Ngawen, Gunungkidul. 
Telah diuraikan pada awal tulisan ini, bahwa studi pasar merupakan fenomena yang menarik, karena menyangkut aspek perilaku manusia dalam melaksanakan aktivitas perekonomian sehari-hari, apalagi dikaitkan dengan tradisi Jawa yang dikenal dengan pranata mangsa. Pada hari pasaran, pasar-pasar tradisional memegang peran yang sangat sentral, yakni penting bagi seluruh kehidupan masyarakat sekitarnya. Hal tersebut disebabkan karena pada hari itu berdasarkan konsep pikir masyarakat Jawa, adalah hari pasaran (pon, wage, kliwon, dan legi) baik untuk melakukan perjalanan, transaksi jual-beli, dan banyak orang berkumpul. Jika melakukan aktivitas pada harihari yang telah ditentukan, diharapkan dapat membawa keberuntungan.

Terkait dengan konteks hari pasaran tersebut, lebih penting diperhatikan adanya istilah di dalam prasasti yang sering disebut Pinarimandala Cinaturdesa, yang kurang lebih berarti pinari $=$ pari $=$ umum $/$ menyeluruh, mandala $=$ wilayah. Cinaturdes $a=$ dibatasi empat desa. Dengan demikian kurang lebih dapat diartikan bahwa setiap desa ditentukan batas-batasnya dengan desa-desa yang lain. Desa/ mandala tempat tinggal pendeta bisa terletak di tengah dari desa-desa yang lain di sekitarnya. Jadi satu desa di tengah, dikelilingi oleh empat desa di sekitarnya. ${ }^{5}$ Selain itu. Adanya konsep mancapat di dalam kehidupan masyarakat desa di Jawa. Konsep tersebut, salah satunya menentukan letak sebuah desa satu dengan yang lainnya, yakni satu desa di tengah/ pancer sebagai sentrumnya, biasanya dikelilingi oleh empat desa lainnya pada masing-masing sisi mata anginnya (utara, timur, selatan dan barat). Namun, hal tersebut juga dipengaruhi oleh letak geografis/ bentang lahan dan alam sekitar desa pancer tersebut, sehingga pola-pola desa yang ada disekitarnya dapat dibagi menjadi dua golongan: Pola pertama, penuh artinya, di keempat mata angin terdapat desa yang lainnya. Sedangkan, pola kedua, tidak penuh; pada ke empat mata angin hanya terdapat dua atau tiga desa terdekat.

Perilaku pedagang saat melakukan mobilitas sangat menarik karena menggunakan berbagai cara dan peralatan yang sesuai dengan jenis barang dagangannya. Beberapa pedagang seperti gerabah, dan burung masih banyak melakukan dengan cara alami, yakni dengan dipikul maupun digendong. Hal tersebut tentunya tidak jauh berbeda dengan perilaku pedagang pada masa klasik, yakni dalam melakukan distribusi dan komoditi, baik berupa bahan mentah maupun bahan jadi, dari tempat asal ke tempat pembuatan dan terakhir penjualan (pasar) dilakukan dengan berbagai cara. Untuk jalur darat dalam prasasti disebut mahawan (=melalui jalan). Pedagang-pedagang dari daerah pedalaman yang melalui jalur darat dan mengangkut barang dagangnya dalam jumlah terbatas menggunakan kuda atau sapi. Atau kadangkala diangkut sendiri oleh pemiliknya dengan dipikul (pinikul dagangannya) (Nastiti, 1988).

5 Wawancara dengan Bapak M.M. Sukarto K. Atmodjo, pada bulan Januari, tahun 1998 di Yogyakarta. Beliau adalah seorang epigraf. 
Oleh karena itu, dengan melihat perilaku, jenis konsumsi, peralatan yang digunakan, dan persepsi-persepsi para pedagang pasar tradisional akan banyak pemahaman baru yang dapat kita peroleh, guna mengetahui perilaku masyarakat pada masa sebelumnya (zaman kebudayaan Hindhu dan Budha) di Jawa, khususnya pada aspek ekonominya.

\section{KEPUSTAKAAN}

Albiladiyah, Ilmi, S, dan Suratmin, 1977. Kotagede Pesona dan Dinamika Sejarahnya, Lembaga Studi Jawa, Yogyakarta.

Bertrand, Alvin, L, 1978. Rural Sociology, Book Company Inc, London.

Bintarto, R. dan Surastopo, H, 1978. Metode Analisa Geografi, LP3ES, Jakarta.

Goris, 1948. Sejarah Bali Kuna.

Lelono, H. (1994). Neptu Dalam Prasasti Jawa Bali (Makna Psiko-Religius). Berkala Arkeologi, 14(2), 60-63. https://doi.org/10.30883/jba.v14i2.645

Murniatmo, Gatut, dkk, 1982. Sistem Ekonomi Tradisional Sebagai Perwujudan Tanggapan Masyarakat Terhadap Lingkungannya Di Daerah Istimewa Yogyakarta. Depdikbud, Dirjen Kebudayaan, Direktorat Sejarah Dan Nilai Tradisional, Jakarta.

Murtolo, Ali Sudarmo, dkk, 1995. Dampak Pembangunan Pasar Ekonomi (Pasar) Terhadap Kehidupan Sosial Budaya Masyarakat Daerah Istimewa Yogyakarta. Depdikbud, Direktorat Sejarah dan Nilai Tradisional, Bagian Proyek Pengkajian Dan Pembinaan Nilai-Nilai Budaya Daerah Istimewa Yogyakarta, 1995/1996.

Nastiti, Titi Surti, 1988. Perdagangan Pada Masa Majapahit, Paper, AHPA Trowulan 7 -- 11 November.

Suyono, Ariyono, 1985. Kamus Antropologi, Akademika Pressindo, Jakarta.

Wibisono, Sonny Chr, 1988. Subyek dan Obyek Arkeologi-Ekonomi, Paper, AHPA Trowulan 7 -- 11 November. 